\title{
The Europe without borders discourse and splitting European identities
}

\section{Carsten Yndigegn}

\begin{abstract}
The aim of this paper is to trace and scrutinize some of the underlying forces that might contribute to explaining the current skepticism about a policy of debordering Europe. The author therefore discusses why prefiguring a borderless Europe based on European identity has stumbled into misconceived conceptions of the nation, and then presents an explanation of the transformative dynamics that undermine the vision of a borderless Europe. The paper concludes that a borderless Europe will remain a vision as long as the idea of a European identity cannot establish a reliable alternative to its national counterpart, but multiple cosmopolitan forces still keep pushing towards debordering Europe.
\end{abstract}

\section{Keywords}

Borderless Europe, European identity, nationalism, populism, rebordering

\section{The end of an epoch?}

Regardless of whether it has been a grand delusion or simply the consequence of the end of permissive consensus, we cannot escape the fact that the conceptual framework that forms the basis for the idea of a borderless Europe is being challenged and may already be eroded. The idea of European unification paired with internal debordering has been a key element in the vision for the development of a European Community and the European Union; however, the European construction that has been presented as the outcome of European integration now increasingly seems a controversial goal.

Since the flow of refugees in 2015, exemptions from the Schengen Agreement that used to be rare and based on exceptional situations have been introduced in several European countries, and permanent border control has been reintroduced along several internal Schengen borders. Furthermore, an emerging discourse is that European integration has gone 
too far in eroding national borders and that "our" nation is better served by leaving the Union. Brexit in the United Kingdom was a radical example, but similar demands have been raised even in core member states (Dennison/Pardijs 2016).

The main drivers in the rebordering discourse that has emerged are critical views on democracy, on mobility and immigration, on the issue of "social Europe", and on the perforation of external borders. All such issues add fuel to the fire that threatens the pragmatic visionary transformation of the European continent after WW2.

In this paper, the theoretical approach to borders is founded on the tradition that was established in the 1990s by a mix of geographers, political scientists, sociologists, and anthropologists (Donnan/Wilson 1994; Kavanagh 1994; Agnew 1996; Paasi 1996; Newman/Paasi 1998). It established a new border paradigm that replaced the classic concept of borders based on the idea that "states establish borders to secure territories which are valuable to them because of their human or natural resources, or because these places have strategic or symbolic importance to the state" (Wilson/ Donnan 1998, p. 9). The new border concept focused on people, not spatial and institutional aspects of borders. It envisaged that institutional borders maintain a role in framing mentalities. Borders play a role similar to culture that develops unevenly, which Ogburn (1922) has expressed as a cultural lag in the process of social change: "The thesis is that the various parts of modern culture are not changing at the same rate, some parts are changing much more rapidly than others". (Ogburn quoted in Volti 2004, p. 397). This is formulated exemplarily by John Agnew:

Borders are artefacts of dominant discursive processes that have led to the fencing off of chunks of territory and people from one another. Such processes can change and as they do, borders live on as residual phenomena that may still capture our imagination but no longer serve any essential purpose. Borders, therefore, are not simply practical phenomena that can be taken as given. They are complex human creations that are perpetually open to question. At an extreme, perhaps, existing borders are the result of processes in the past that are either no longer operative or are increasingly eclipsed by transnational or global pressures. In other words, borders are increasingly redundant, and thinking constrained by them restricts thinking about alternative political, social, and economic possibilities. (Agnew 2008, p. 176)

Furthermore, this paper builds on Etienne Balibar's idea of globalized borders. Balibar proposes that borders have become polysemic (Balibar 2004) and vacillating (Balibar 1998). On the one hand, they keep on framing na- 
tion state sovereignty, and on the other hand, they allow unhindered flow across the borders for some and continue to be a barrier to others. They take on different meanings, for example as passable gateways or barriers, which Balibar terms "detention zones and filtering systems" (Balibar 2004, p. $111)$; or as Rumford puts it: "Borders can remain invisible to the many while bordering out the few" (Rumford 2008, p. 38).

According to Balibar, globalized borders have moved from the periphery of a nation, or the "edge of the territory" as he says, "into the middle of political space" (Balibar 2004, p. 109). The reason is that global flows differentiate between the human and the non-human. Material and immaterial entities (traded goods, financial assets) flow freely, whilst the flow of people is regulated by borders that are located in many places.

The aim of this paper is to trace and scrutinize some of the underlying forces that might contribute to explaining the current skepticism about a policy of debordering Europe that has been in effect for six decades. The paper does not pretend to offer a comprehensive view, since it cannot cover the totality of discourse within the EU, and it adopts a one-sided perspective, the perspective taken being from the northern part of Europe. Its focus will be on political attitudes, public discourse and conceptual frames. I will completely refrain from analyzing institutional policy.

The paper is divided into four parts. First, I will discuss the vision of a borderless Europe; then I will discuss why prefiguring a borderless Europe based on European identity has stumbled into misconceived conceptions of the nation and its transformability. The third part will go into more detail, presenting an explanation of the transformative dynamics that seem to so successfully undermine the vision of a borderless Europe; and finally, I will discuss the prospects for a borderless Europe, where the cosmopolitan vision seems outdated, but multiple cosmopolitan forces still keep pushing towards debordering Europe.

\section{The vision of a borderless Europe}

The vision of a borderless Europe, in a broader sense of a unified group of countries cooperating together, has a long history. Europe's past as a continent of warring states (Heffernan 1998; Roche 2010, p. 103-105) has led contemporary thinkers to develop ideas and models for a unified Europe. Figures such as Saint-Simon, Coudenhove-Kalergi and Aristide Briand in particular are leading lights in the history of visions of European identitybuilding (Delanty 1995; Pagden 2002). However, all visionary proposals have fallen short when confronted with Realpolitik. 
Since WW2, the vision of a "Europe without borders" has been a main driver in efforts to develop European integration. The founding fathers shared the common experience of the devastating consequences of populism that quickly turned into totalitarianism, and some of them-Konrad Adenauer, Alcide De Gasperi and Robert Schuman-were exposed to severe personal suffering. Furthermore, both De Gasperi and Schumann shared the experience of living in contested border regions and the heritage of military confrontation arising from that. They realized the necessity of putting an end to the vicious circle of war by establishing integrative mechanisms that neutralized the key drivers behind military confrontation, by replacing them with incentives for peaceful cooperation (Martín de la Torre 2014).

The removal of borders for trade, finance and communication has been successful. The "borderlessness" in these areas is not necessarily a European phenomenon. This is exactly what is behind global trade agreements within the framework of the WTO, and the so-called deregulated economy or globalization that have been prevalent over the past thirty years.

Moreover, the idea of debordering found support in cosmopolitan discourse. Ulrich Beck, who builds on Kant's idea of living in one world and being a citizen of the whole world (Beck 2003), perceives the development of cosmopolitanism as inevitable. He proposes that a change from the national to the global perspective is required because of transborder activities or cross-border behavior by national citizens who, as he says, shop, work, love, marry, research, grow up, and are educated internationally. And as he observes, they:

live and think transnationally, that is, combine multiple loyalties and identities in their lives [and therefore] the paradigm of societies organized within the framework of the nation state inevitably loses contact with reality. (Beck 2000, p. 80)

Therefore, borders are eroded and transnationality negates the borders of the nation state and thereby dissolves the exclusive status of the nation state, which can no longer close its borders to protect its citizens. In Beck's words, cosmopolitanism is an expression of "how far social structures and institutions are becoming transnationalized" (Beck 2003, p. 21). However, such manifestations of freedom have also met with criticism from the political left, and they have been criticized as symptoms of the unlimited expansion of a neo-liberal world order (Della Porta/Tarrow 2005; Della Porta 2006; Volscho/Kelly 2012).

The development of borderless personal mobility has been promising. The more limited idea of free movement for Europe's workforce, as laid 
out in the Treaty of Rome, has been transformed into an almost universal right of mobility for all European citizens within the European Union. And the signing and implementation of the Schengen Agreement succeeded in giving it a narrower, concrete reality, by removing control posts at physical border crossings, which themselves had been a visual symbol of a national border.

However, the development of a borderless Europe within the fourth of the freedoms of the EU seems to have reached its limits. Three factors indicate that the process towards a borderless Europe is itself reaching its limits: 1) Britain's exit from it, with mobility as a key issue; 2) the reintroduced border controls in parts of the Schengen area; and 3) Euroskeptic right-wing populist movements gaining momentum.

Opening borders and establishing contact and interaction have been the driving components for visions of the development of a transnational European identity. The assumption was that narrow nationalistic feelings and prerogatives would diminish, while cross-border solidarity and recognition of universal needs and rights would thrive.

The opposite happened. The sympathetic idea of European identity ended up being a scapegoat for the consequences of globalization. This leads to questions as to whether the idea of open borders and a European commonality has just been an illusionary vision based on epistemological failures, and whether the realization of a borderless Europe released counterforces with a dynamic power that had not been foreseen in academic theories.

\section{The contested model of European identity}

It is the proposition of this paper that the concept of European identity as a precondition of a borderless Europe has encountered epistemological obstacles that are caused by it having been modelled on an essentialist conception of national identity. To put it simply, this means that national identity is being perceived as something that has developed within a specific historical, territorial and demographic context. From a particular perspective, this can seem to imply that national identity has always existed, and that it is linked to a durable and unchangeable native population within a given territory. However, this is an over-simplification.

There are two positions as regards the relation between concepts of national and European identity. One excludes the transformation from national identity to European identity, and the other conceptually prefigures the possibility of such a transformation, given that the necessary precondi- 
tions have been established. I will challenge these positions by invoking Anthony D. Smith and Jürgen Habermas respectively.

Anthony Smith anchors the social construction of national identities in historical memories. He stresses the necessity of a generational continuity that binds together the population, either as a whole or as units, and with the help of shared memories and the collective belief in a destiny common to this group of people (Smith 1992, p. 58).

In a paper from the early 1990s, Anthony Smith claimed that a European identity modelled on the concept of national identity was not possible, because national identity is defined as a product of a common historical legacy, shared traditions and a shared heritage. And this, he claimed, is exactly what Europe lacks:

There is no European analogue to Bastille or Armistice Day, no European ceremony for the fallen in battle, no European shrine of kings or saints. When it comes to the ritual and ceremony of collective identification, there is no European equivalent of national [...] community. (Smith 1992, p. 73)

Habermas has proposed a strong counter-argument to such historicist naturalization of collective identities. He proposes citizenship as the unifying element in a political construction, but he emphasizes that "the democratic right of self-determination includes, of course, the right to preserve one's own political culture, which includes the concrete context of citizen's rights, though it does not include the self-assertion of a privileged cultural life form" (Habermas 1992, p. 17). From his point of view, a collective identity is not a cultural or an ethnic identity, but a politically constituted identity. It is not bound to a static historical continuity, but is open to the dynamic possibilities implicit in social change: "Our task is less to reassure ourselves of our common origins in the European Middle Ages than to develop a new political self-confidence commensurate with the role of Europe in the world of the twenty-first century" (Habermas 1992, p. 12).

Drawing on the lessons from the creation of nation states, Habermas notices that it was possible to gradually produce a national consciousness and "solidarity amongst strangers", and he claims that this was in no way different from what would be required today for a European identity to develop. National consciousness was produced gradually "with the help of national historiography, mass communication, and universal conscription. If that artificial form of "solidarity amongst strangers" came about thanks to a historically momentous effort of abstraction from local, dynastic consciousness to a consciousness that was national and democratic, then why 
should it be impossible to extend this learning process beyond national borders?" (Habermas 1999, p. 58).

Here, Habermas is in line with Benedict Anderson (1991), who demonstrated how a national identity is not restricted to the commonality of a geographically demarcated people, but goes beyond the realm of experience. Anderson proposed the idea of an imagined community, a shared common territory wherein the inhabitants presumed to know each other. In so doing, he showed that the concept of national identity is a social construction and, in this way, he is entirely in line with the epistemological preconditions for a European identity.

For many years, the development of a European identity was a clear strategy of the European Union. The development of a European identity has been furthered by initiatives such as The European Capital of Culture (Sassatelli 2009; Immler/Sakkers 2014; Lähdesmäki 2014) and the Erasmus, now Erasmus+, educational and youth exchange programs (Ambrosi 2013; Striebeck 2013; Van Mol 2013; Mitchell 2015). However, despite the high priority of the EU's policies, identification with Europe has remained low, far behind local and national identifications, and often on a par with identification with the world as a whole. Changing the focus from separate identities to multiple identities has given new insights into the complexity of the formation of European identity (Moreno et al. 1998; Marks/Hooghe 2003; Moreno 2006; cf. Bruter 2008).

For a European identity to develop, Habermas sets four requirements to be fulfilled: a European constitution, a party system built around transnational political interests, the creation of a European public sphere, and the establishment of a common communicative framework based on the teaching of foreign languages in the school system. The EU does have a constitutional framework, but not a European constitution. European political parties are in the making. The European public sphere is developing, while the consciousness of European interdependency is increasing. Finally, the lingua franca, i.e. English, has been established and disseminated in a rapidly spreading process. However, even the most positive evaluation of the progress made can only conclude that the process is still in its infancy.

Still valid is the observation already made by Kohli (2000) that people identify themselves as European only as a multiple identity. As Kohli says, "if identity is conceived of as a multilevel set of attachments, Europe is now a part of it for the majority of its citizens. If, on the other hand, one clings to an exclusionary concept of identity, European attachment is still highly minoritarian" (Kohli 2000, p. 125). European identity has never become a popular project, but remained a project for the elite or the cos- 
mopolitan, and that is precisely what has opened up as its vulnerability in times of renewed nationalism.

\section{Restorative dynamics}

The resistance to the idea of a united Europe without borders is not new. The European integration project has never been uncontested. The stance taken by the British Prime Minister, Margaret Thatcher, is an exemplary representation of the skepticism about a borderless Europe. In 1988, she gave her Bruges speech, warning against the centralization and bureaucratization of the EU: "We have not successfully rolled back the frontiers of the state in Britain only to see them reimposed at a European level with a European superstate exercising a new dominance from Brussels." (Thatcher 1988).

In her Bruges speech, Margaret Thatcher laid out a principle of minimal integration. With regard to borders, Thatcher admitted that it should be made easier for people to travel across the borders, but at the same time she stated that border controls should be maintained to protect "citizens from crime and stop the movement of drugs, of terrorists and of illegal immigrants" (Thatcher 1988). This is strikingly similar to what is said today by the new right-wing populists. In 2011, ten years after the implementation of the Schengen Treaty, the Danish People's Party negotiated the implementation of a border control camouflaged as customs control with the Danish government (Ministry of Finance 2011). This was proclaimed as a victory on their website, because, as they wrote:

Denmark is again on track to being safe.... We are setting up physical checkpoints, on the borders with both Germany and Sweden-and at all Danish ports and all Danish airports. In addition to permanently manning the borders with many customs officers-with the police backstage-brand new, fancy equipment will be installed. ... It has been a wonderful 10 years for all sorts of suspicious types-gunrunners, drug smugglers, illegal immigrants, criminal burglars-who were free to swoop in across the borders of Denmark in their large, closed vans. That's over now! (Dansk Folkeparti 2011) (translated from the Danish).

Looking more generally at resistance to the open border aspect of European integration, we can say that two major developments have served as obstacles. Internal mobility and external immigration have between them caused social change in Europe and generated grievances that have led to 
political mobilization and the creation of social movements to promote opposition to the enforced changes. Labor mobility within the EU, continuous immigration from the Middle East, the Caucasus and Africa, combined with the massive influx of asylum seekers, primarily from Syria in 2015 , have unleashed reactionary, restorative forces among the populations in the countries affected. The demand for enforced border control is only the visual evidence of the forces that have been set in motion. Underneath, much stronger border work is playing out as a reaction against what has been perceived as national elites becoming disengaged from common people, thereby breaking the bonds that establish national unity and identity.

External border control has been an ongoing policy of the EU, but despite measures taken in the form of the European Neighbourhood Policy (ENP) and Frontex, the external borders, known less than euphemistically as Fortress Europe, have not been watertight. It was, however, only when massive refugee influxes and migration flows found a new path, the socalled Balkan route, that national governments were forced to suspend the Schengen Agreement and reintroduce border controls. This was done either because the immigration of asylum seekers had risen to levels which national immigration frameworks were unable to cope with, as was the case in Sweden, or because the mass influx of asylum seekers allowed rightwing populists to mobilize themselves successfully in its wake.

In the case of Sweden, the end of the open borders policy came suddenly. It used to be the policy of all parties except those on the extreme right, most recently the Sweden Democrats, that Sweden should be a safe haven for refugees from across the world, and that no restrictions should be imposed on the number of asylum seekers that the country could receive. That official policy was based on a welcoming culture of open Swedish hearts, which former Prime Minister Fredrik Reinfeldt has embodied since he took office in 2006. Reinfeldt argued that immigration should be unlimited, because civilizational gains have been caused by an influx of people and ideas from abroad. Furthermore, he argued that Sweden does not belong to certain people just because they have resided in the country for three or four generations, or because they have managed to erect a border (Redaktionen 2006; Nationen 2014). However, in 2015, when Sweden received more asylum seekers per inhabitant than any other European country, immigration became unmanageable and the government suspended the Schengen rules and introduced border controls.

Across the rest of Europe, border policies have been strengthened as well. Europe became divided between those mainly Eastern European countries that refused immigrants, and those who received them in varying degrees. Among the latter, stricter policies towards asylum seekers de- 
veloped as the governments found themselves faced with the swiftly growing support that right-wing populist parties received when they turned against immigrants. German chancellor Angela Merkel's expression "Wir schaffen das!" reflected the country's administrative ability to handle the refugee crisis but not its political ability to handle the negative reactions among the electorate. Border control was reinstated to stem the tide, but this was too late to close the floodgates of political reaction that had been opened (Hockenos 2017; Hoerner/Hobolt 2017; Mushaben 2017; Sinn 2017; Stelzenmüller 2017).

\subsection{The populist tidal wave}

All over Europe, parties opposing immigration have gained momentum. Their influence is measurable not only in the support for right-wing populists but is even more evident in the policy changes that have been adopted by mainstream parties.

Right-wing populist movements against asylum seekers as a phenomenon have been seen for decades, but, however annoying, their mobilization has so far not been threatening at the political level. However, this has changed, because a series of disparate trends have merged to form a major stream.

The first such trend is the phenomena relating to the internal development of the EU. There are three main allegations put forward against the EU. The first is the claim that there is a lack of democracy in its decisionmaking. As has been put forward by scholars studying the EU, this argument is gaining strength mainly because national governments' participation in EU decisions is disconnected from the national political process (Ladrech 2007; Häge 2008; Colombatto 2014; Hobolt/Tilley 2014; cf. Macron 2017).

The second trend lies in the antipathy toward the mobility of workers from Eastern Europe, and so-called 'welfare tourists', who are personally blamed for acting in accordance with arrangements European governments agreed upon at the beginning of the 2000s (Remeur 2013). EU politicians believed that mobility would further the convergence of social welfare, i.e. a more equal distribution of social benefits, but this was a belief that was never accepted by ordinary citizens, because its implementation went hand in hand with austerity policies and social security provisions that were further undermined by neo-liberal deregulation (Guild et al. 2013; Blauberger/Schmidt 2014; Fernandes 2016). 
The third and last trend is the emergence of certain forms of criminality taking place in or emerging out of a sphere that is beyond the purely national. This covers both cross-border crime, which is experienced as trafficking, drug dealing, burglaries, economic fraud, etc., but also the development of new forms of criminal behavior within societies. Although the discrepancy between the level of actual crime and perceived crime is huge, the consequences of the perception bias should not be underestimated (Lange et al. 2008; Kersten 2016; Huffington Post 2017; Pfeiffer et al. 2018).

The fourth trend is globalization, which represents a policy of open borders for finance and trade. In her Bruges speech, Margaret Thatcher pointed out that this required politicians to free up markets, widen choice, and reduce government intervention. As she said: "Our aim should not be more and more detailed regulation from the centre: it should be to deregulate and to remove the constraints on trade" (Thatcher 1988). The consequences of these neo-liberal policies have been impossible to overlook. The welfare state and the public sector have been transformed into a competition state (Yeatman 1993; Cerny 1997; Levi-Faur 1998; Lavenex 2007; Evans 2010; Vukov 2016). The labor market has been deregulated and companies have outsourced and been offshored, while at the same time unions have lost their ability to secure the solidarity and the interests of those still working or aspiring to do so (Peters 2008). The precariat (Standing 2011) is one visual example of the outcome of such policies; another is the slide into poverty that has meant the working poor working longer hours for less, and being flexible 24/7 (Fraser et al. 2011; Van Lancker 2011; Walsh/Zacharias-Walsh 2011).

Those exposed to the consequences of these changes, and who are able to compare the present day with the past, might echo Marx and Engels' famous expression about the changes that the bourgeois industrial revolution caused: "All that is solid melts into the air." Those threatened by the constant disappearance of workplaces, witnessing the increased influx of foreign workers, and becoming increasingly uneasy and insecure as they see residential areas and local communities transformed, these people turn towards those who address the phenomena they recognize and who speak about them in a language they understand or use (Inglehart/Norris 2016). Their grievances fuel the rise of right-wing populism and demands to control the borders. 


\subsection{Profiling right-wing populism}

Claus Offe has framed the contemporary rise of right-wing populist movements with concise clarity:

Populist mobilization relies on the (vertical) mobilization of distrust (of political elites and intermediary institutions-mendacious media ( $L \ddot{u}$ genpresse), academia, experts, civil society associations, also courts)and the (horizontal) spreading of fear of outsiders. Migrants/refugees are ideally suited as objects of fearmongering for three reasons:

- Economic: they threaten us in the labor and housing markets and live at the expense of our taxes;

- Cultural: allegedly incompatible language, religion, ethnic identity;

- Failures of state protection: rape, crime, terrorism.

Distrust is particularly effective when the two can be combined: elites are to be distrusted because they fail to protect us from or are even actively promoting (Merkel in September 2015) the access of migrants. (Offe 2017)

If we take this a step further, Ignazi (2003) has delivered a precise diagnosis of the underlying value scheme that guides the grievances of the followers of right-wing populist groups and makes them targets for the mobilization of the new populist right. Ignazi describes how right-wing populist movements are solidly founded on nationalism, and how their political focus is a quest for "harmonious unity":

The national, local or ethnic community must be preserved against any sort of division. Pluralism is extraneous to the extreme right political culture: unity, strength, harmony, nation, state, ethnos, Volk are the recurrent references. [...] They cannot conceive of a community where people are not "similar" one to another, because differences would entail division. (Ignazi 2003, p. 145)

With this conception, right-wing populists justify closing the borders to protect against the immigration of non-Western people, especially Muslims, because their presence is perceived as a cultural threat to the nation state and the national culture. The right-wing populists also single out the supporters of a multicultural society as traitors. This tactic was first described by Bjørgo (1997), the Norwegian researcher of right-wing extremism. Right-wing populist defamatory and humiliating attacks on the elite, the "swamp" that needed to be drained, has continued until the present day (Norris 2017). 
Mondon has shown this in an analysis of the French Front National, which targets as its enemies "globalization (mondialisme) and human rights, which threatened to destroy national identities" (2015, p. 398). This is, however, not a form of exceptionalism, as new populist movements founded on this dichotomy have emerged in almost all European countries.

In some European countries, this approach has been even more pronounced. In Hungary and Poland, populist regimes have used their newly obtained power to change constitutions and remold public institutions and other aspects of the political and intellectual framework in order to ensure that the policy changes they have introduced, and their hold on power, become irreversible (Albright/Woodward 2018; Appelbaum 2018).

The most important aspect of right-wing populist movements is not the grievances they exploit to mobilize support or the claims they make, but the fact that the strongest of them have maintained their course now for three decades, and during this period they have morphed from being pariahs to having mainstream respectability. Mondon (2015) has shown this in an exemplary analysis of the French Front National. The party profits from the left's inability to address social changes, and it mobilizes support around a subtle form of racism, which Mondon calls "new racism", which, instead of targeting ethnicity, stresses the incompatibility of cultures (Mondon 2015, p. 402).

Populists perceive themselves as grounded territorially, culturally, and socially in a specific place, and they perceive themselves as having the right of the first-born. Jan-Werner Müller has expressed this with distinct clarity: "Populism, then, is not about a particular social base or a particular set of emotions or particular policies; rather, it is a particular moralistic imagination of politics, a way of perceiving the political world which opposes a morally pure and fully unified, but ultimately fictional, people to small minorities who are put outside the authentic people" (Müller 2014, p. 485).

Ostracism, as practiced in ancient Greek society to control the elite, is not a proper populist strategy today. Protection therefore has to be established up front. The rise of right-wing populism has led to a strong claim for the rebordering of Europe on multiple levels, and national governments have in varying degrees adjusted their policies to accommodate the grievances that have fueled the right-wing populist mobilization. Even seemingly liberal intellectuals such as David Goodhart, the former director of the British think tank Demos, blends his voice with those who raise concerns that society is becoming too diverse (Goodhart 2004). In so doing, he becomes a supporter of a restrictive immigration policy from another an- 
gle. He simply claims that "the slow disappearance [...] of the rather miraculous, and historically unique, institution of the modern welfare state" (Goodhart 2013, p. 261) is being caused by increased diversity in society, which undermines solidarity, because the welfare state presupposes a "homogenous society with intensely shared values" (Goodhart 2013, p. 262). The propositions of Goodhart find support in recent research. Putnam (2007) in the US, Schmidt-Catran and Spies (2016) in Germany, and Eger (2010) in Sweden all found that solidarity diminishes in communities characterized by immigration and ethnic diversity, and in the European context, that support for welfare has been negatively influenced by immigration.

Increasingly, public discourse is moving toward Goodhart's position. This establishes a paradox for progressives who both want social diversity through open borders and a welfare state. While at first the position of Goodhart was heavily criticized, now there is a multiple echoing of his opinions outside the right-wing populist camp (Skidelsky 2017). Cottakis (2018) calls this the "adoption approach", because the change might reflect subjection to a dominant trend, not a proper and timely reaction to it. It takes over populist positions instead of confronting them. The alternative, the "counter-vision" approach, debunks populists' unsubstantiated promises and presents attractive alternatives. This approach, Cottakis argues, has been used successfully by the French president, Emmanuel Macron (Cottakis 2018).

\section{Discussion}

The epistemological basis for a justification of debordering the nation state has been addressed in the literature of cosmopolitanism. It offers alternative perspectives to the positions of nationalism and populism, and as Khan has pointed out, its roots are to be found in the German philosopher Kant, who outlined a theory of cosmopolitan law and a universal moral community, "where a violation of rights in one part of the world is felt everywhere" (Kant quoted in Khan 2014, p. 129). According to Khan, the theory of cosmopolitan law "extends the rights citizens enjoy as members of a sovereign state to non-citizens" (Khan 2014, p. 129). From a similar position, Vanessa Barker has criticized the seemingly most liberal Swedish migration policy for being anchored in ethnic nation state principles (Barker 2012; Barker 2017a; Barker 2017b; Barker 2018). Furthermore, it has been argued that despite the launch of the "rights to rights" discourse, and regardless of all proclamations and conventions, universal human 
rights are still framed by national citizenship and the will of nation states: "The expansion of global human rights will continue to depend on individual countries' citizens' political rights" (Shafir/Brysk 2006, p. 285).

However, as Nobel Prize-winning economist, Robert Shiller, has pointed out, the pressure from those being born at a remove from Western sources of wealth will not accept that such arbitrariness should determine their chances in life, and he foresees that this will drive an intellectual revolution that will "challenge the economic implications of the nation state" (Shiller 2016; cf. Abram et al. 2017).

This is the continuing conflict that will continue to pose a threat to the idea and reality of a borderless Europe. The response to the challenge from a majority of the population might seek support in variants of populism that combine an economically liberal and a national conservative approach with a Euroskeptic position (Decker 2016), or variants that combine a classical social democratic welfare state approach with national conservatism and Euroskepticism.

This conflict will persist as long as the idea of a European identity cannot establish a reliable alternative to its national counterpart. As long as the nation state is seen as the basic protective force in the life of citizens, and an integrated Europe adds to the threat instead of being perceived as a reliable response to global challenges, the obstacles to a debordered Europe will persist.

\section{References}

Abram, Simone, et al. (2017): The free movement of people around the world would be Utopian: IUAES World Congress 2013: Evolving Humanity, Emerging Worlds, August 5-10, 2013. In: Identities 24, no. 2, p. 123-155, https:// doi.org/10.1080/1070289X.2016.1142879.

Agnew, John (1996): Review of Territories, Boundaries and Consciousness: The Changing Geographies of the Finnish-Russian Border by Anssi Paasi. In: Geografiska Annaler. Series B, Human Geography 78, no. 3, p. 181-182, https:// doi.org/10.2307/490833.

Agnew, John (2008): Borders on the mind: re-framing border thinking. In: Ethics \& Global Politics 1, no. 4, p. 175-191. https://doi.org/10.3402/egp.v 1i4.1892.

Albright, Madeleine Korbel/Woodward, William (2018): Fascism: a warning. New York: Harper.

Ambrosi, Gioia (2013): The Influence of the ERASMUS Programme on Strengthening a European Identity: Case Studies of Spanish and British Exchange Students. In: Feyen, B./Krzaklewska, E. (eds.): The ERASMUS phenomenon: symbol of a new European generation? Frankfurt am Main: Lang Lang, p. 143-162. 
Anderson, Benedict (1991): Imagined Communities: Reflections on the Origin and Spread of Nationalism. London: Verso.

Appelbaum, Anne (2018): A Warning From Europe. The Atlantic Magazine. Boston: The Atlantic.

Balibar, Etienne (1998): The borders of Europe. In: Cheah, P./Robbins, B. (eds.): Cosmopolitics: thinking and feeling beyond the nation. Minneapolis: University of Minnesota Press, p. 216-229.

Balibar, Etienne (2004): We, the people of Europe? Reflections on transnational citizenship. Princeton NJ: Princeton University Press.

Barker, Vanessa (2012): Nordic Exceptionalism revisited: explaining the paradox of a Janus-faced penal regime. In: Theoretical Criminology 17, no. 1, p. 5-25, https://doi.org/10.1177/1362480612468935.

Barker, Vanessa (2017a): Nordic vagabonds: the Roma and the logic of benevolent violence in the Swedish welfare state. In: European Journal of Criminology 14, no. 1, p. 120-139, https://doi.org/10.1177/1477370816640141.

Barker, Vanessa (2017b): Penal power at the border: realigning state and nation. In: Theoretical Criminology 21, no. 4, p. 441-457. https://doi.org/ 10.1177/1362480617724827.

Barker, Vanessa (2018): Nordic nationalism and penal order: walling the welfare state. London/New York: Routledge.

Beck, Ulrich (2000): The cosmopolitan perspective: sociology of the second age of modernity. In: British Journal of Sociology 51, no. 1, p. 79-105, https://doi.org/ 10.1111/j.1468-4446.2000.00079.x.

Beck, Ulrich (2003): Rooted Cosmopolitanism: Emerging from a Rivalry of Distinctions. In: Beck, U. et al. (eds.): Global America? The cultural consequences of globalization. Liverpool: Liverpool University Press, p. 15-29.

Bjørgo, Tore (1997): Racist and right-wing violence in Scandinavia: patterns, perpetrators, and responses. Oslo: Tano Aschehoug.

Blauberger, Michael/Schmidt, Susanne K. (2014): Welfare migration? Free movement of EU citizens and access to social benefits. In: Research \& Politics 1, no. 3, p. 1-7, https://doi.org/10.1177/2053168014563879.

Bruter, Michael (2008): Legitimacy, Euroscepticism \& Identity in the European Union - Problems of Measurement, Modelling \& Paradoxical Patterns of Influence. In: Journal of Contemporary European Research 4, no. 4, p. 273-285.

Cerny, Philip G. (1997): Paradoxes of the Competition State: the Dynamics of Political Globalization. In: Government and Opposition 32, no. 2, p. 251-274, https://doi.org/10.1111/j.1477-7053.1997.tb00161.x.

Colombatto, Enrico (2014): The EU and the euro are easy targets in political blame-game. In: United Europe. https:/www.united-europe.eu/2014/09/the-euand-the-euro-are-easy-targets-in-political-blame-game, 5/22/2018.

Cottakis, Michael (2018): How to tackle populism: Macron vs Kurz. In: EUROPP - European Politics and Policy. https://blogs.lse.ac.uk/europpblog/2018/02/13/ how-to-tackle-populism-macron-vs-kurz, 2/13/2018. 
Dansk Folkeparti (2011): Danmarks granser igen på vej til at blive sikre [Online]. Copenhagen. https://web.archive.org/web/20110929043317/; https:// www.danskfolkeparti.dk/Gr\%C3\%A6nsekontrol.asp, 11/9/2017.

Decker, Frank (2016): The "Alternative for Germany": Factors Behind its Emergence and Profile of a New Right-wing Populist Party. In: German Politics and Society 34, no. 2, p. 1-16, https://dx.doi.org/10.3167/gps.2016.340201.

Delanty, Gerard (1995): Inventing Europe: Idea, Identity, Reality. London: Macmillan.

Della Porta, Donatella (2006): The Antiglobalisation and the European Union: Critics of Europe. Brussels: European Commission.

Della Porta, Donatella/Tarrow, Sidney (2005): Transnational protest and global activism. Lanham Md.: Rowman \& Littlefield.

Dennison, Susi/Pardijs, Dina (2016): The world according to Europe's insurgent parties: Putin, migration and people power. London: European Council on Foreign Relations.

Donnan, Hastings/Wilson, Thomas M. (eds.) (1994): Border Approaches: anthropological perspectives on frontiers. Lanhan MD: University Press of America.

Eger, Maureen A. (2010): Even in Sweden: The Effect of Immigration on Support for Welfare State Spending. In: European Sociological Review 26, no. 2, p. 203217, https://doi.org/10.1093/esr/jcp017.

Evans, Mark (2010): Cameron's competition state. In: Policy Studies 31, no. 1, p. 95-115, https://doi.org/10.1080/01442870902899871.

Fernandes, Sofia (2016): Access to social benefits for EU mobile citizens: "tourism" or myth? Policy Paper 168. Berlin: Jacques Delors Institut.

Fraser, Neil, et al. (2011): Working poverty in Europe: a comparative approach. Basingstoke: Palgrave Macmillan.

Goodhart, David (2004): Too diverse? In: Prospect 2004, February, p. 1-7. https://w ww.prospectmagazine.co.uk/magazine/too-diverse-david-goodhart-multicultural ism-britain-immigration-globalisation, 6/24/2016.

Goodhart, David (2013): The British dream: successes and failures of post-war immigration. London: Atlantic Books.

Guild, Elspeth, et al. (eds.) (2013): Social benefits and migration a contested relationship and policy challenge in the EU. Brussels: Centre for European Policy Studies (CEPS)

Habermas, Jürgen (1992): Citizenship and National Identity: some reflections on the Future of Europe. In: Praxis International 12, no. 1, p. 1-19.

Habermas, Jürgen (1999): The European nation-state and the pressures of globalization. In: New Left Review, no. 235, p. 46-59.

Häge, Frank M. (2008): Who Decides in the Council of the European Union? In: JCMS: Journal of Common Market Studies 46, no. 3, p. 533-558, https:// doi.org/10.1111/j.1468-5965.2008.00790.x.

Heffernan, Michael (1998): War and the shaping of Europe. In: Graham, B. (ed.): Modern Europe: Place, Culture and Identity. London: Arnold, p. 89-120. 
Hobolt, Sara Binzer/Tilley, James (2014): Blaming Europe? Responsibility without accountability in the European Union. Oxford: Oxford University Press.

Hockenos, Paul (2017): East Germans and the far-right AfD: the roots of far-right support in East Germany go far deeper than Merkel's immigration policies. In: International Politics and Society, https:/www.ips-journal.eu/regions/europe/ article/show/east-germans-and-the-far-right-afd-2315, 10/5/2017.

Hoerner, Julian M./Hobolt, Sara (2017): The AfD succeeded in the German election by mobilising non-voters on the right, https://blogs.lse.ac.uk/europpblog/ 2017/09/29/the-afd-succeeded-in-the-german-election-by-mobilising-non-voterson-the-right/?utm_source=feedburner\&utm_medium=email\&utm_campaign $=$ Feed $\% 253 \mathrm{~A}+$ Europp $+($ EUROPP +-+ European + Politics + and + Policy + at +LSE), 9/29/2017.

Huffington Post (2017): So entlarvte der Kriminologe Christian Pfeiffer bei Maischberger die Panikmache der AfD. Huffington Post, 11/30/2017.

Ignazi, Piero (2003): The Development of the Extreme Right at the End of the Century. In: Merkl, P. H./Weinberg, L. (eds.): Right-wing extremism in the twentyfirst century. London: Frank Cass.

Immler, Nicole L./Sakkers, Hans (2014): (Re)Programming Europe: European Capitals of Culture: rethinking the role of culture. In: Journal of European Studies 44, no. 1, p. 3-29, https://doi.org/10.1177/0047244113515567.

Inglehart, Ronald/Norris, Pippa (2016): Trump, Brexit, and the rise of populism: economic have-nots and cultural backlash. HKS Working Paper No. RWP16-026. Cambridge, MA: Harvard Kennedy School.

Kavanagh, William (1994): Symbolic boundaries and 'real' borders on the Portuguese-Spanish frontier. In: Donnan, H./Wilson, T. M. (eds.): Border Approaches: anthropological perspectives on frontiers. Lanhan MD: University Press of America, p. 75-88.

Kersten, Joachim (2016): Flüchtlingskrise, Männergewalt und „Stranger Danger“: Anmerkungen zur Köln-Debatte. In: NK Neue Kriminalpolitik 28, no. 4, p. 367-377, https://doi.org/10.5771/0934-9200-2016-4-367.

Khan, Gulshan (2014): Jürgen Habermas and the Crisis of the European Union. In: Demetriou, K. N. (ed.): The European Union in crisis: explorations in representation and democratic legitimacy. New York: Springer, p. 123-139.

Kohli, Martin (2000): The Battlegrounds of European Identity. In: European Societies 2, no, 2, p. 113-137, https://doi.org/10.1080/146166900412037.

Ladrech, Robert (2007): National Political Parties and European Governance: The Consequences of 'Missing in Action'. In: West European Politics 30, no. 5, p. 945-960, https://doi.org/10.1080/01402380701617365.

Lähdesmäki, Tuuli (2014): Discourses of Europeanness in the reception of the European Capital of Culture events: the case of Pécs 2010. In: European Urban and Regional Studies 21, no. 2, p. 191-205, https://doi.org/ $10.1177 / 0969776412448092$.

Lange, Hans-Jürgen, et al. (2008): Auf der Suche nach neuer Sicherheit: Fakten, Theorien und Folgen. Wiesbaden: VS Verlag für Sozialwissenschaften. 
Lavenex, Sandra (2007): The competition state and highly skilled migration. In: Society 44, no. 2, p. 32-41, https://doi.org/10.1007/BF02819924.

Levi-Faur, David (1998): The competition state as a neomercantilist state: Understanding the restructuring of national and global telecommunications. In: The Journal of Socio-Economics 27, no. 6, p. 665-685, https://doi.org/10.1016/ S1053-5357(99)80002-X.

Macron, Emmanuel (2017): Initiative for Europe: speech by Emmanuel Macron, President of the French Republic, 26 September 2017. Paris: Présidence de la République.

Marks, Gary/Hooghe, Liesbet (2003): National Identity and Support for European Integration. Discussion Paper SP IV 2003-202. Berlin: Wissenschaftszentrum Berlin für Sozialforschung (WZB).

Martín de la Torre, Victoria (2014): Europe, a leap into the unknown: a journey back in time to meet the founders of the European Union. Brussels: Peter Lang.

Ministry of Finance (2011): Permanent toldkontrol i Danmark (styrket grænsekontrol) (Permanent Customs Check in Denmark (Strengthened Border Control)). Copenhagen: Ministry of Finance, https://www.eu.dk/da/nyheder/2015/ graensekontrol, 11/7/2017.

Mitchell, Kristine (2015): Rethinking the 'Erasmus Effect' on European Identity. In: JCMS: Journal of Common Market Studies 53, no. 2, p. 330-348, https:// doi.org/10.1111/jcms.12152.

Mondon, Aurelien (2015): The French secular hypocrisy: the extreme right, the Republic and the battle for hegemony. In: Patterns of Prejudice 49, no. 4, p. 392413, https://doi.org/10.1080/0031322X.2015.1069063.

Moreno, Luis (2006): Scotland, Catalonia, Europeanization and the 'Moreno Question'. In: Scottish Affairs, 54. https://www.euppublishing.com/doi/10.3366/ scot.2006.0002.

Moreno, Luis, et al. (1998): Multiple identities in decentralized Spain: the case of Catalonia. In: Regional \& Federal Studies 8, no. 3, p. 65-88, https://doi.org/ $10.1080 / 13597569808421060$.

Müller, Jan-Werner (2014): 'The people must be extracted from within the people': Reflections on Populism. In: Constellations 21, no. 4, p. 483-493, https:// doi.org/10.1111/1467-8675.12126.

Mushaben, Joyce Marie (2017): Angela Merkel's Leadership in the Refugee Crisis. In: Current History 116, no. 788, p. 95-100, http://www.currenthistory.com/ Article.php?ID=1393.

Nationen (2014): Fredrik Reinfeldt: Sweden belongs to the immigrants - not the Swedes [Online], https://www.youtube.com/watch?v=d5pPmcYUHVU, 7/8/2016.

Newman, David/Paasi, Anssi (1998): Fences and Neighbours in the postmodern world: boundary narratives in the Postmodern World. In: Progress in Human Geography 22, no. 2, p. 186-207, https://doi.org/10.1191/030913298666039113. 
Norris, Pippa (2017): Why populism is a threat to electoral integrity [Online]. London: London School of Economics and political science. https://blogs.lse.ac.uk/ europpblog/2017/05/16/why-populism-is-a-threat-to-electoral-integrity, $5 / 16 / 2017$.

Offe, Claus (2017): Germany: What Happens Next? In: Social Europe https:// www.socialeurope.eu/germany-happens-next, 10/3/2017.

Ogburn, William Fielding (1922): Social change with respect to culture and original nature. New York: B.W. Huebsch, Inc.

Paasi, Anssi (1996): Territories, Boundaries and Consciousness: the changing geographies of the Finnish-Russian Border. Chichester: John Wiley \& Sons.

Pagden, Anthony (ed.) (2002): The idea of Europe: From antiquity to the European Union. Cambridge: Cambridge University Press.

Peters, John (2008): Labour market deregulation and the decline of labour power in North America and Western Europe. In: Policy and Society 27, no. 1, p. 8398, https://doi.org/10.1016/j.polsoc.2008.07.007.

Pfeiffer, Christian, et al. (2018): Zur Entwicklung der Gewalt in Deutschland. Schwerpunkte: Jugendliche und Flüchtlinge als Täter und Opfer. Zürich: Zürcher Hochschule für Angewandte Wissenschaften, Institut für Delinquenz und Kriminalprävention.

Putnam, Robert D. (2007): E Pluribus Unum: Diversity and Community in the Twenty-first Century. The 2006 Johan Skytte Prize Lecture. In: Scandinavian Political Studies 30, no. 2, p. 137-174, https://doi.org/10.1111/ j.1467-9477.2007.00176.x.

Redaktionen (2006): Reinfeldt: Det ursvenska är blott barbari [Online]. Stockholm: Dagens Nyheter. https:/www.dn.se/nyheter/politik/reinfeldt-det-ursvenska-ar-bl ott-barbari, 7/8/2016.

Remeur, Cécile (2013): Welfare benefits and intra-EU mobility: Library Briefing. Brussels: Library of the European Parliament.

Roche, Maurice (2010): Exploring the sociology of Europe: an analysis of the European social complex. Los Angeles Calif.: SAGE.

Rumford, Chris (2008): Cosmopolitan spaces: Europe, globalization, theory. New York: Routledge.

Sassatelli, Monica (2009): Becoming Europeans: cultural identity and cultural policies. Basingstoke: Palgrave Macmillan.

Schmidt-Catran, Alexander W./Spies, Dennis C. (2016): Immigration and Welfare Support in Germany. In: American Sociological Review 81, no. 2, p. 242-261, https://doi.org/10.1177/0003122416633140.

Shafir, Gershon/Brysk, Alison (2006): The Globalization of Rights: From Citizenship to Human Rights. In: Citizenship Studies 10, no. 3, p. 275-287, https:// doi.org/10.1080/13621020600772073.

Shiller, Robert J. (2016): The Coming Anti-National Revolution. In: Project Syndicate https://prosyn.org/4KLfVw6, 9/19/2016.

Sinn, Hans-Werner (2017): Germany’s Götterdämmerung. In: Project Syndicate. https://www.project-syndicate.org, 11/26/2017. 
Skidelsky, Robert (2017): Inconvenient Truths About Migration. In: Project Syndicate https://prosyn.org/BYoUlm6, 11/22/2017.

Smith, Anthony D. (1992): National identity and the idea of European unity. In: International Affairs 68, no. 1, p. 55-76, https://doi.org/10.2307/2620461

Standing, Guy (2011): The precariat: the new dangerous class. London: Bloomsbury Academic.

Stelzenmüller, Constanze (2017): After the election, Germany's democracy faces its hardest test since 1949. Washington: Brookings Institution Press.

Striebeck, Jennifer (2013): A Matter of Belonging and Trust: The Creation of a European Identity through the ERASMUS Programme? In: Feyen, B./Krzaklewska, E. (eds.): The ERASMUS phenomenon: symbol of a new European generation? Frankfurt M.: Lang-Ed., p. 191-206.

Thatcher, Margaret (1988): Speech to the College of Europe: 'The Bruges Speech', https://www.margaretthatcher.org/document/107332, 7/5/2016.

Van Lancker, Wim (2011): The European world of temporary employment. In: European Societies 14, no. 1, p. 83-111, https://doi.org/ 10.1080/14616696.2011.638082.

Van Mol, Christof (2013): ERASMUS Student Mobility and the Discovery of New European Horizons. In: Feyen, B./Krzaklewska, E. (eds.): The ERASMUS phenomenon: symbol of a new European generation? Frankfurt M.: Peter Lang, p. 163-174.

Volscho, Thomas W./Kelly, Nathan J. (2012): The Rise of the Super-Rich. In: American Sociological Review 77, no. 5, p. 679-699, https://doi.org/ 10.1177/0003122412458508.

Volti, Rudi (2004): William F. Ogburn: Social Change with Respect to Culture and Original Nature. In: Technology and Culture 45, no. 2, p. 396-405, https:// www.jstor.org/stable/40060750.

Vukov, Visnja (2016): The rise of the Competition State? Transnationalization and state transformations in Europe. In: Comparative European Politics 14, no. 5, p. 523-546, https://doi.org/10.1057/cep.2016.20.

Walsh, John P./Zacharias-Walsh, Anne (2011): Working longer, living less: understanding Marx through the workplace today. In: Kivisto, P. (ed.): Illuminating social life: classical and contemporary theory revisited. Thousand Oaks Calif: Pine Forge Press, p. 5-40.

Wilson, Thomas M./Donnan, Hastings (1998): Nation, state and identity at international borders. In: Wilson, T. M./Donnan, H. (eds.): Border Identities: Nation and State at International Frontiers. Cambridge: Cambridge University Press, p. $1-30$.

Yeatman, Anna (1993): Corporate managerialism and the shift from the welfare to the competition state. In: Discourse: Studies in the Cultural Politics of Education 13, no. 2, p. 3-9, https://dx.doi.org/10.1080/0159630930130202. 


\section{About the author}

Carsten Yndigegn | University of Southern Denmark | Department of Political Science and Public Management | Centre for Border Region Studies | Alsion 2 | 6400 Sønderborg | Denmark | T +4565501764 | cy@sam.sdu.dk

Carsten Yndigegn holds a Ph.D. in Cultural Studies. He is an Associate Professor Emeritus at the Centre for Border Region Studies in the Department of Political Science and Public Management at the University of Southern Denmark. He has specialized in media and youth studies. His recent research interests have focused on debordering Europe, the development of European identity, and nationalism, populism and Euroskepticism. He was the national project manager for the EU FP7 research project MYPLACE (2011-2015), about how the shadows of totalitarianism and populism in Europe influence young people's social and political participation. 